\title{
Kitchen Organic Waste as Material for Vermiculture and Source of Nutrients for Plants
}

\author{
Joanna Kostecka', Mariola Garczyńska ${ }^{1 *}$, Agnieszka Podolak', \\ Grzegorz Pączka', Janina Kaniuczak²
}

! Department of Natural Theories of Agriculture and Environmental Education, Faculty of Biology and Agriculture, University of Rzeszów, 35-601 Rzeszów, Ćwiklińskiej 1A Str., Poland

2 Department of Soil Science, Environmental Chemistry and Hydrology, Faculty of Biology and Agriculture, University of Rzeszów, 35-601 Rzeszów, Ćwiklińskiej 1A Str., Poland

* Corresponding author's e-mail: mgar@ur.edu.pl

\begin{abstract}
Departure from waste storage and maximisation of its utilization is currently the basis of modern waste management. This is favoured by the requirements defined in numerous legal instruments, including both EU directives and local regulations of member states. This also applies to organic waste, especially kitchen waste, which, with adequate education of the public, may constitute waste resources of very good quality to produce e.g. vermicomposts. It is very important, since soils of most European countries require continuous supply of organic matter to replenish humus and nutrients for the plants. The paper describes current trends in the production of kitchen organic waste. Since such waste has been vermicomposted for many years, advantages of this biotechnology have been presented and features of the produced vermicomposts have been characterised.
\end{abstract}

Keywords; kitchen organic waste, earthworms, vermicompost

\section{BACKGROUND}

Organisation of sustainable development and circular economy requires departure from waste storage and maximisation of its recycling. In Poland, this is favoured by the requirements specified in numerous legal instruments, starting from the Thematic Strategy on Soil Protection [Thematic Strategy on Soil Protection...], through the Regulation of the Minister of the Environment of 20 January 2015 on the process of R10 recovery (Journal of Laws of the Republic of Poland [Dz. U. RP], item 132), Regulation of the Minister of Economy of 16 July 2015 on landfill waste disposal (Journal of Laws of the Republic of Poland [Dz. U. RP], item 1277), and ending with the National Waste Management Plant [The National Waste Management Plan] [KPGO 2022]. This also applies to organic waste, especially kitchen waste, which, with adequate education of the public and its participation in the creation and operation of waste management, may constitute waste resources of very good quality to produce composts and vermicomposts. This is even more important due to the fact that agricultural soils in Europe require continuous supply of organic matter to replenish humus and nutrients for the plants. In Poland, this is especially important due to a high proportion of light soils, since water and air relations in these soils cause a naturally lower content of organic matter than in heavy soils.

Increase in agricultural productivity of weak soils and improvement in the physico-chemical properties of marginal soils should be primarily directed towards soil enrichment in organic material. Production of nitrogen and phosphorus fertilisers is highly energy-using and also causes ecological problems. Therefore, with regard to economy and ecology, the source of nutrients for plants should be various types of organic waste. Thus, one of the objectives of the National Waste Management Plan [KPGO 2022] is to depart from 
waste storage and to maximize utilization of the macro- and microelements included in the waste, e.g. N, P, Ca, Mg, Cu, Zn, Mn, Mo. Apart from including precious nutrients, it should also meet the requirements specified for mineral and organicmineral fertilisers [The Fertilisers and Fertilisation Act.]. The Research Centre of the European Commission recommends the following procedure: to avoid biowaste disposal, but the choice of an appropriate way of its processing should result from specific local factors (Krutwagen et al. 2008). This necessitates constant research on various methods of its final disposal.

In Europe, the highest amount of municipal waste produced annually per one person (including biodegradable kitchen waste) is produced by highly-developed countries [Eurostat 2016, FUSIONS 2016]. The conclusion is obvious: organic waste of household origin should be considered as an appropriate component for improvement of soil qualities. Household organic waste, if properly segregated by aware citizens, is a very good source of material to produce fertilisers, although this is in contrast with a still preferred form of its disposal, i.e. combustion. It must be emphasised that although we can then produce our own energy (which would be called renewable by some people), if we deal with clean waste of e.g. potential food, then, from the point of view of sustainable development and circular economy, this is highly disadvantageous. It causes an ultimate loss of resource and a gap in the system of potential recirculation.

The aim of the study was to present selected qualities of the kitchen organic waste production. Since the authors of the publication have been vermicomposting such waste for many years, advantages of this biotechnology have been exposed and features of the produced vermicomposts have been characterised.

\section{METHOD}

The method included analysis of selected literature and results of studies conducted on vermicomposting of kitchen waste with the use of 2 worm species: Eisenia fetida Sav. and Dendrobaena veneta Rosa.

Two mixtures of waste have been vermicomposted: mixture (a) apple, carrot and beetroot juice pomace, potato residues + cellulose at a ratio of 4:1 and mixture (b) apple peelings + potatoes + pasta + bread + cellulose at a ratio of $2: 1$.
In the stratification layer, waste and resulting vermicompost, determination of carbon was conducted by the Turin's method; $\mathrm{N}$ - by the Kjeldahl method, $\mathrm{pH}$ in $\mathrm{H}_{2} \mathrm{O}$ - was determined by a potentiometric method, conductance $(\mathrm{mS})$ and salinity $\left(\mathrm{g} \mathrm{NaCl} \cdot \mathrm{dm}^{-3}\right)$ - by a conductometric method, phosphorus - by a vanadium-molybdenum method, colorimetrically using UV-VIS spectrophotometer from Shimadzu UV-2600. Potassium was analysed with an atomic absorption spectrophotometer Hitachi Z-2000, with the use of emission method (EAAS), while calcium and magnesium - using an atomic absorption spectrophotometer Hitachi Z-2000, with the use of flame method (FAAS). $\mathrm{C} / \mathrm{N}$ ratio was calculated.

\section{RESULTS}

\section{Kitchen organic waste}

With regard to household waste, biodegradable waste constitutes the highest proportion (30$60 \%$ ). It is produced during preparation of meals and also comes from food, paper and cardboard residues which are thrown away. FAO warns that about one third of the food produced in the world is wasted (Gustavsson et al. 2011). Collection and analysis of data from the whole Europe regarding the route of food delivery (from production to consumption) shows that in $27 \mathrm{EU}$ member states, food wasting reaches about 89 million $\mathrm{Mg}$ waste a year, out of which 12.3 million Mg is restaurant waste. In 2009, this corresponded to 179 $\mathrm{kg}$ of waste per year/person (Monier et al 2010; European Commission (DG ENV)). During the same period, e.g. Poland produced about 9 million $\mathrm{Mg}$ of food waste (about 6.5 million $\mathrm{Mg}$ of waste from food industry, about 2 million $\mathrm{Mg}$ of household waste and about 350 thousand $\mathrm{Mg}$ of waste from food services) (Sapek 2013).

Data from another period - year 2012 from 28 EU member states showed the same trend towards food wasting. During that period, this negative social and environmental phenomenon was at a level of 88 million $\mathrm{Mg}$ of food waste, which corresponded to $173 \mathrm{~kg}$ of food waste per person. This estimate included both kitchen waste produced at consumption and inedible parts related to food production (FAO 2014; FUSIONS 2016).

Wasteful consumption of food is currently perceived as a problem with serious ethical, ecological and economic consequences. There- 
fore, the European Commission promotes continuous reduction of food wasting and assumes reduction of this phenomenon by half by 2020 . However, implementation of effective preventive measures is very complicated. Such activities require knowledge of the causes and scale of food waste production in the entire chain of food delivery. The available data base for Europe is highly varied and there are justified reservations to its reliability(Bräutigam et al. 2014).

However, certain qualities of biodegradable kitchen waste are useful for processing in vermiculture (Kostecka et al. 2018). Most of all, it is important that such waste is accumulated gradually, so it may be administered to worms as food, e.g. at the site of its production.

\section{Vermicomposting}

Vermicomposting, next to fermentation and composting, is one of the examples of pro-environment biotechnology allowing processing of organic waste (Adi and Noor 2009; Domínguez and Edwards 2011a; Pączka and Kostecka 2012). While composting involves cooperation of macroorganisms and microorganisms, for which the processed matter is a source of energy, vermicomposting is a process using concentrated worm populations to decompose the supplied organic matter. The product of this process is vermicompost fertiliser and biomass of worm epitheliomuscular tubes (Sherman 2003; Garg et al. 2005; Domínguez and Edwards 201lb).

Due to a high content of microflora and nutrients facilitating plant growth, vermicompost is called "black gold" (Adhikary 2012). It is a homogeneous, granular structure with a pleasant odour and dark brown colour. The resulting fertiliser contains components which are easily available for plants, including nitrogen, phosphorus and potassium. This is due to the fact the alimentary tract of worms contains microorganisms converting insoluble forms of elements into forms available for plants. Vermicompost improves soil characteristics and affects the quality of crops; therefore it is a part of pro-environment practices (Adhami et al. 2014; Padmavathiamma et al 2008; Song et al 2015). The use of vermicompost has been studied with regard to fertilisation of such plants as tomato, cucumber, potato, celery, leek, pepper, spinach, strawberry, bean or pea (Kostecka and Błażej 2000; Arancon et al. 2003; Singh et al. 2008; Pączka and Kostecka 2013; Kadam and Pathade
2014; Kashem et al. 2015; Song et al. 2015). Nevertheless, this issue requires further studies, since the quality of the produced fertiliser, its chemical composition and effect on plant growth and development depend on the type of waste which is converted by the worms.

Another product of vermicomposting is worm biomass. It may be used, for example, as food for fish, including aquarium fish, which may contribute to the reduction of costs related to fish cultivation and cause faster growth of the fish (Kostecka and Pączka 2006).

A so called "worm ecological box" is an example of a practical and pro-environment smallscale waste recycling. This is a container with a capacity adequate for the planned amount of processed waste including worms which are regularly supplied with organic waste. Such culture may function in the cellar, on the balcony or in the family garden. Such processing of waste may be an inexpensive, but effective, tool of everyday utilization of kitchen organic waste (Kostecka 2000; Kostecka et al. 2018).

Vermicompost productivity depends of the conditions created for the worms in the conducted culture (Kostecka 1994; Sherman 2003). Successful vermicomposting also depends on the structure and composition of organic waste administered to the worms. This is confirmed by studies on potential vermiculture utilization of such waste as e.g. banana tree leaves adequately mixed with bovine manure (Padmavathiamma et al. 2008), horse manure (Sangwan et al. 2008), goat manure (Loch et al. 2005), grape pomace (Paradelo et al. 2009), coffee grounds (Adi and Noor 2009), sediments from waste treatment plants (Parvaresh et al. 2004), kitchen organic waste (Kostecka et al. 1999), paper industry waste (Gajalakshmi et al. 2002; Gupta and Garg 2009), plant residues (Bansal and Kapoor 2000), mushroom waste (Kostecka 2000) or ground textile waste (Kaushik and Garg 2003). Not all organic waste in its pure form guarantee process productivity. Waste of animal origin, such as meat residues or bones, as well as certain kitchen waste, e.g. garlic, onion or chilli are not willingly processed (Adhikary 2012).

Worm cultures may include accompanying fauna which competes for space and food. A combined activity of these animals may accelerate or slow down the undergoing transformations. Vermiculture may also be endangered by excessive concentration of worms, as well as by moles, birds, ants or rats (Kostecka 2000; Adhikary 2012). 


\section{Chemical composition of the obtained vermicomposts}

Processing of mixture a (apple, carrot and beetroot juice pomace, potato residues + cellulose at a ratio of $4: 1$ ) of kitchen organic waste by the population of $E$. fetida and D. veneta resulted in vermicomposts of dark colour, characteristic fine structure and scent of garden soil.

These vermicomposts differed in $\mathrm{pH}$, conductance and the content of potassium and magnesium. They did not differ in the content of phosphorus or calcium. All the above parameters were characterised with significantly increased values in the produced fertilisers in comparison with the stratification medium layer (Table 1).

The comparison of $\mathrm{pH}(p<0.001)$ and conductance $(p<0.001)$ of the obtained vermicomposts showed differences depending on the species of worms producing them. The vermicompost resulting from decomposition of waste by $D$. veneta had higher $\mathrm{pH}$, and lower conductance. It was also characterised with a higher potassium content $(p<0.001)$ as compared with the vermicomposts produced with the use of E. fetida, and it was also characterised with a higher magnesium content $(p<0.001)$.

The examined vermicomposts did not differ from one another $(p>0.05)$ with regard to nitrogen, phosphorus or calcium content, although the values were higher in the vermicomposts produced by $D$. veneta.

Processing of mixture $b$ (apple peelings + potatoes + pasta + bread + cellulose at a ratio of $4: 1)$ by the population of both worm species re- sulted in vermicomposts of similar colour with a fine structure and no residues of unprocessed waste. Vermicomposting did not involve odour production (i.e. was odourless). Again, a comparison of the resulting vermicomposts showed that the worm species affected both $\mathrm{pH}(<0.001)$, and conductance of the obtained vermicomposts $(p<0.01)$ (Table 2$)$. Similarly to mixture a, the vermicompost obtained from transformation of waste mixture b by $D$. veneta had higher $\mathrm{pH}$ and was characterised with lower salinity (and lower conductance) than the vermicomposts produced by E. fetida.

A comparison of other features of vermicomposts resulting from mixture $b$ showed that the vermicomposts differed in the content of total nitrogen $(p<0.01)$ and calcium $(p<0.01)$. Unlike with mixture a, the vermicomposts coming from the containers cultured with E. fetida had a higher nitrogen content, and those produced by $D$. veneta had a higher calcium content. Both vermicomposts obtained from mixture $b$ did not differ in the content of the other nutrients (phosphorus, potassium and magnesium) ( $>0.05)$ (Table 2).

\section{DISCUSSION}

Waste is a problematic issue, since it affects matter circulation, causes loss in the agricultural and forest production space and requires increased financial resources to create landfill sites, costs of their operation and then recultivation. That is why new ways to limit those problems are currently needed, also with regard to organic

Table 1. Comparison of mean chemical composition of the stratification layer and vermicomposts obtained by processing of mixture (a) of kitchen organic waste by populations of E fetida and D. veneta $(\overline{\mathrm{X}} \pm \mathrm{SD})$

\begin{tabular}{|c|c|c|c|c|}
\hline \multirow{2}{*}{\multicolumn{2}{|c|}{ Parameters* }} & \multirow{2}{*}{ Stratification layer } & \multicolumn{2}{|c|}{ Vermicompost } \\
\hline & & & E. fetida & D. veneta \\
\hline \multicolumn{2}{|c|}{$\mathrm{pH}$ in $\mathrm{H}_{2} \mathrm{O}$} & $5,02 \mathrm{a} \pm 0,09$ & $7,17 b \pm 0,22$ & $7,63 c \pm 0,13$ \\
\hline conductance & $\mathrm{mS}$ & $0,65 a \pm 0,06$ & $3,81 b \pm 0,43$ & $3,44 c \pm 0,32$ \\
\hline salinity & $\mathrm{g} \cdot \mathrm{dm}^{-3}$ & $0,98 a \pm 0,09$ & $5,71 \mathrm{~b} \pm 0,64$ & $5.17 \mathrm{c} \pm 0,48$ \\
\hline C & \multirow{6}{*}{$\%$} & $33.28 a \pm 0,33$ & $22.65 b \pm 0,75$ & $23.24 b \pm 1.01$ \\
\hline $\mathrm{N}$ & & $0.83 a \pm 0,01$ & $1.50 \mathrm{~b} \pm 0,05$ & $1.56 b \pm 0,12$ \\
\hline $\mathrm{P}$ & & $0.10 a \pm 0.01$ & $0.29 b \pm 0.02$ & $0.31 \mathrm{~b} \pm 0.05$ \\
\hline K & & $0.09 a \pm 0.01$ & $1.59 \mathrm{~b} \pm 0.07$ & $1.88 c \pm 0.13$ \\
\hline $\mathrm{Ca}$ & & $1.37 a \pm 0.13$ & $2.19 b \pm 0.20$ & $2.30 b \pm 0.21$ \\
\hline $\mathrm{Mg}$ & & $0.08 a \pm 0.01$ & $0.19 b \pm 0.01$ & $0.20 c \pm 0.01$ \\
\hline \multicolumn{2}{|c|}{$\mathrm{C} / \mathrm{N}$} & 40.1 & 15.1 & 14.9 \\
\hline
\end{tabular}

* dry matter.

a, b, c- significant differences between the stratification layer and vermicomposts. 
Table 2. Comparison of mean chemical composition of vermicomposts obtained by processing of mixture (b) of kitchen organic waste by populations of E fetida and D. veneta $(\overline{\mathrm{x}} \pm \mathrm{SD})$

\begin{tabular}{|c|c|c|c|}
\hline \multirow{2}{*}{\multicolumn{2}{|c|}{ Parameters }} & \multicolumn{2}{|c|}{ Wermicompost } \\
\hline & & E.fetida & D.veneta \\
\hline \multicolumn{2}{|c|}{$\mathrm{pH}$ in $\mathrm{H}_{2} \mathrm{O}$} & 5,24 a $\pm 0,18$ & $6,19 b \pm 0,01$ \\
\hline conductance & $\mathrm{mS}$ & $3.36 \mathrm{a} \pm 0.77$ & $2.65 b \pm 0.05$ \\
\hline salinity & $\mathrm{g} \cdot \mathrm{dm}^{-3}$ & $4,68 \mathrm{a} \pm 1,15$ & $3,98 b \pm 0.08$ \\
\hline C & \multirow{6}{*}{$\%$} & 44.98 a \pm 9.88 & $27.19 b \pm 3.13$ \\
\hline $\mathrm{N}$ & & $2.79 a \pm 0.68$ & $1.65 b \pm 0.19$ \\
\hline $\mathrm{P}$ & & $0.05 a \pm 0.01$ & 0.05 a \pm 0.01 \\
\hline K & & $0.25 a \pm 0.03$ & $0.28 a \pm 0.01$ \\
\hline $\mathrm{Ca}$ & & $0.40 \mathrm{a} \pm 0.02$ & $0.50 b \pm 0.01$ \\
\hline $\mathrm{Mg}$ & & $0.05 a \pm 0.01$ & 0.06 a \pm 0.01 \\
\hline \multicolumn{2}{|c|}{$\mathrm{C} / \mathrm{N}$} & 16.1 & 16.5 \\
\hline
\end{tabular}

a, b - statistically significant differences between vermicomposts produced by two worm species.

waste. Specially interesting and simple solutions are related to vermicomposting, including vermicomposting at the site of waste production (in homes, restaurants and at marketplaces) (Kostec$\mathrm{ka}$ et al. 2018). In the future, this may result in a smaller amount of waste thrown away to disposal chutes and sewage systems, and may also reduce costs of waste transport to distant places, i.e. landfill sites or large composting plants. Although, in fact, such ideas are currently too innovative and time-consuming for many citizens, the Fertilisers and Fertilisation Act (2018) provides for vermicomposting (chapter 1, article $2.1 \mathrm{sec}-$ tion 5)), and accepting such method of disposal requires development of special educational programmes. Spreading those ideas will be of great ecological and economic importance. Organic kitchen waste is accumulated gradually, so it may be administered to worms as food in "ecological boxes" (Kostecka et al. 2014, 2018).

Currently conducted studies showed that the quality of the produced vermicompost depends on the worm species, which is consistent with previously conducted studies by Padmavathiamma et al. (2008). Kostecka and Paczka (2011) analysed differences in the vermicompost composition depending on the concentration of $E$. fetida. They showed that a technology based on frequent thinning of the population of vermicomposting worms had a positive effect on $20 \%$ reduction of mean vermicompost salinity $(\mathrm{p}<0.001)$. With regard to the content of basic nutrients for plants, they showed a significantly higher increase in the content of assimilable potassium $(\mathrm{p}<0.001)$, nitrate nitrogen $(p<0.001)$, phosphorus $(p<0.001)$, magnesium $(p<0.001)$ and calcium $(p<0.05)$. The $\mathrm{pH}$ values in ${ }_{\mathrm{H} 2 \mathrm{O}}$, in the resulting fertilisers did not change. Regarding the whole picture of plant nutrition requirements, the use of the technology based on frequent separation of medium and worm population was much more advantageous.

Kostecka et al. (1999) noticed differences in the content of ash, organic matter, nitrogen, potassium, calcium, iron, copper, manganese, zinc, sodium and nickel between the vermicomposts produced by groups of species dominated by the Enchytraeidae or worms in the utilization media. This might result from different nutrient demand in both groups, which naturally formed biocenosis in the vermiculture media. The present differences may also be explained in a similar way. Nevertheless, this provokes further research.

Another issue worth further research is a problem of determining the vermicompost maturity. In much earlier studies, Kołodziej and Kostecka (1994) proposed a method to assess vermicompost directly in the culture site, which is practical for breeders. The method involved determination of assimilable plant nutrients in the produced vermicomposts and was to indicate a satisfactory level of the waste medium mineralization by worms. These authors, based on the analysis of vermicomposts from 121 field cultures and a vermicompost from an experimental and didactic culture conducted in the University of Agriculture in Krakow, Branch in Rzeszow (in 1992-1993), performed determinations of the contents of nitrate nitrogen and assimilable forms of phosphorus, potassium, calcium and magnesium in acetic acid by Spruvay method modified by 
Nowosielski, and determinations of the total content of these components in sulphuric acid. They proposed minimum values indicating a sufficient level of mineralization. Specific values referred to the vermicomposts from bovine manure and with determination of the content diluted in 0.03 $\mathrm{n}$ acetic acid (from manure of $75-80 \%$ humidity) they amounted to: $250 \mathrm{mg} \mathrm{NO} \cdot \mathrm{dm}^{-3}$ for nitrate nitrogen; $800 \mathrm{mg} \cdot \mathrm{dm}^{-3}$ for assimilable phosphorus; $1400 \mathrm{mg} \cdot \mathrm{dm}^{-3}$ for assimilable potassium; $1000 \mathrm{mg} \cdot \mathrm{dm}^{-3}$ for assimilable calcium and 5000 $\mathrm{mg} \mathrm{NO} \cdot \mathrm{dm}^{-3}$ for assimilable magnesium.

Currently most authors applies the method of vermicompost maturity determination to assessment of changes in the $\mathrm{C} / \mathrm{N}$ ratio in the obtained fertilisers. With regard to kitchen waste, depending on the mixture of vermicomposted waste and the worm species (e.g. kitchen wasted mixed with bagasse at a ratio of 1:1 vermicomposted by E.fetida (Babaei et al. 2016), household waste $(30 \%)+$ bovine manure $(70 \%)-$ E.fetida (Gupta et al. 2014), household waste + rice straw (1:1) - E.fetida (Hussain et al. 2018), kitchen waste + bovine manure (1:1) E.fetida i Lampito mauritii (Tripathi and Bharadway 2004); the proportion of $\mathrm{C} / \mathrm{N}$ changes described by these authors was in the range between 12 and $53 \%$ - which corresponds to the final $\mathrm{C} / \mathrm{N}$ value of the vermicomposts of 27-21.

It seems that the biggest $\mathrm{C} / \mathrm{N}$ changes occur with vermicomposting of pure kitchen waste. Albasha et al. (2015) after 60 days of vermicomposting with Eudrilus eugenigae, reported a decrease in waste $\mathrm{C} / \mathrm{N}$ from $30.8 \pm 0.12$ to $5.45 \pm 0.13$ (change by $82.3 \%$ ). These assessments, however, also require collection of more abundant data and finding the principle governing the changes depending on the process duration, worm species and composition of the waste mixture.

\section{CONCLUSION}

The whole world faces the serious problem of an increasing amount of waste, including organic waste. This serious threat to the natural environment is a price for rapid civilisation progress. Therefore, more and more attention is directed to improving the waste management system; however, these activities must necessarily involve participation of the public. Vermiculture involves a process in which kitchen organic waste is converted into organic fertiliser containing precious nutrient for plants. This allows for their effective replenishment in soils, and at the same time for sustainable management of European soil resources, the more so that vermicomposts supply the soils with specific organic carbon. Vermicompost production is also a part of solving the problem of organic waste management. The vermicomposts produced from household kitchen waste by means of biotechnological methods using $E$. fetida and $D$. veneta, constitute wholesome organic fertiliser of good chemical composition thanks to the contents of macroelements. As shown by research, the production of vermicomposts and their chemical composition may answer the nutritional needs of plants.

\section{REFERENCES}

1. Adhami E., Hosseini S., Owliaie H. 2014. Forms of phosphorus of vermicompost produced from leaf compost and sheep dung enriched with rock phosphate. International Journal of Recycling of Organic Waste in Agriculture, 3, 68-73.

2. Adhikary S. 2012. Vermicompost, the story of organic gold: A review. Agricultural Sciences. 3, 7, 905-917.

3. Adi A.J., Noor Z.M. 2009. Waste recycling: Utilization of coffee grounds and kitchen waste in vermicomposting. Bioresource Technology, 100, 1027-1030.

4. Albasha M.O., Gupta P., Ramteke P.W. 2015. Management of kitchen waste by vermicomposting using earthworm Eudrilus Eugeniage. 2015. Conference on Advances in Agricultural, Biological \& Environmental Sciences. [Available at: http:// iicbe.org/upload/1869C0715011.pdf (accessed 4 september 2018)].

5. Arancon N.Q., Edwards C.A., Bierman P., Metzger J.D., Lee S., Welch C. 2003. Effects of vermicomposts on growth and marketable fruits of fieldgrown tomatoes, peppers and strawberries. Pedobiologia, 47, 731-735.

6. Babei A.A., Goudarzi G., Neisi A., Ebrahimi Z., Alavi N. 2016. Vermicomposting of cow dung, kitchen waste and sewage sludge. Journal of Advances in Environmental Health Research, 4(2), 88-94.

7. Bansal S., Kapoor K. K. 2000. Vermicomposting of crop residues and cattle dung with Eisenia foetida. Bioresource Technology, 73, 95-98.

8. Bräutigam K.R., Jörissen J., Priefer C. 2014. The extend of food waste generation across Eu-27: Different calculation methods and the reliability of their results. Waste Management \& Research, 32(8), 683-694. 
9. Dominguez J., Edwards C.A. 2011a. Biology and Ecology of Earthworm Species used for Vermicomposting. In: Edwards C.A., Arancon N.Q., Shreman R. (Eds.) Vermiculture technology. Earthworms, organic wastes and environmental management. CRC, Taylor and Francis Group Press. Boca Raton, London, New York, 3, 27-40.

10. Dominguez J., Edwards C.A. 2011b. Relationships between Composting and Vermicomposting. In: Edwards C.A., Arancon N.Q., Shreman R. (Eds.) Vermiculture technology. Earthworms, organic wastes and environmental management. CRC, Taylor and Francis Group Press. Boca Raton, London, New York, 2, 11-25.

11. European Commission (DG ENV), Directorate C - Industry 2010. Preparatory study on food waste across EU 27. [Available at: http://ec.europa.eu/ environment/eussd/pdf/bio_foodwaste_report.pdf (accessed 4 september 2018)].

12. Eurostat 2016. Waste generation and treatment. [Available at: http://epp. eurostat.ec.europa.eu/ cache/ITY_SDDS/EN/env_wasgt_esms.htm\#stat_ pres (accessed 5 June 2015)].

13. FAO (2014) Food balance sheets. [Available at: http://faostat3.fao.org/faostatgateway/go/to/download/FB/*/E (accessed 2 September 2018)].

14. FUSIONS 2016. Reducing food waste through social innovations. Fusions EU project 311972 [Available at: http://www.eufusions.org/phocadownload/Publications/Estimates $\% 20$ of $\% 20 \mathrm{Eu}-$ ropean $\% 20$ food $\% 20$ waste $\% 201$ levels (accessed 2 August 2018)].

15. Gajalakshmi S., Ramasamy E.V., Abbasi S.A. 2002. Vermicomposting of paper waste with the anecic earthworm Lampito mauritii Kingburg. Indian Journal of Chemical Technology, 9, 306-311.

16. Garg V. K. Chand S., Chhillar A., Yadav A. 2005. Growth and reproduction of Eisenia foetida in various animal wastes during vermicomposting. Applied Ecology and Environmental Research, 3, 51-59.

17. Gupta R., Garg V. K. 2009. Vermiremediation and nutrient recovery of non-recyclable paper waste employing Eisenia fetida. Journal of Hazardous Materials, 162, 430-439.

18. Gupta R., Yadav A., Garg V. K. 2014. Influence of vermicompost application in potting media on growth and flowering of marigold crop. International Journal of Recycling of Organic Waste in Agriculture, 3(1), 47-57.

19. Gustavsson J, Cederberg C.,Sonesson U. 2011. Global food losses and food waste: Extent, causes and prevention. Rome: Food and Agriculture Organization of the United Nations (FAO), 1-29.

20. Hussain N., Das S., Goswami L., Das P., Sahariah B. 2018. Intensification of vermitechnology for kitchen vegetable waste and paddy straw employ- ing earthwormconsortium: Assessment of maturity time, microbial structure, and economic benefit. Journal of Cleaner Production, 182, 414-426.

21. Kadam D., Pathade G. 2014. Effect of tendu (Diospyros melanoxylon RoxB.) leaf vermicompost on growth and yield of French bean (Phaseolus vulgaris L.). International Journal of Recycling of Organic Waste in Agriculture, 3, 44-50.

22. Kashem M. A., Sarker A., Hossain I., Islam M. S. 2015. Comparison of the vermicompost and inorganic fertilizers on vegetative growth and fruit production of tomato (Solanum lycopersicum L.). Open Journal of Soil Science, 5, 53-58.

23. Kaushik P., Garg V. K. 2003. Vermicomposting of mixed soil textile mill sludge and cow dung with the epigeic earthworm Eisenia foetida. Bioresource Technology, 90, 311-316.

24. Kołodziej M., Kostecka J. 1994. Method for vermicompost evaluation directly in the earthworm's bed. Metoda oceny wermikompostów bezpośrednio w siedlisku hodowlanym dżdżownic. Zeszyty Naukowe AR w Krakowie. Sesja Naukowa, 41, 95-98. (in Polish).

25. Kostecka J. 1994. Guide for earthworm breeders. Poradnik hodowcy dżdżownic. Akademia Rolnicza w Krakowie. Filia w Rzeszowie, 1-40.

26. Kostecka J. 2000. Badania nad wermikompostowaniem odpadów organicznych. Zeszyty Naukowe AR w Krakowie. Rozprawy, 268, 1-88.

27. Kostecka J., Błażej J. 2000. Growing plants on vermicompost as a way to produce high quality foods. Bull. of the Polish Acad. of Scien. Biol. Scien. 48(1), 1-10. [http://repozytorium.ur.edu.pl/handle/ item/3113].

28. Kostecka J., Garczyńska M., Pączka G. 2018. Food waste in the organic recycling system and a sustainable development. Problems of Sustainable Development, 13(2), 157-164.

29. Kostecka J., Kaniuczak J., Nowak M. 1999. Wybrane cechy wermikompostów z organicznych odpadów domowych. Folia Univ. Agric. Stet. 200. ser. Agricultura, 77, 173-177.

30. Kostecka J., Pączka G. 2006. Possible use of earthworm Eisenia fetida (Sav.) biomass for breeding aquarium fish. European Journal of Soil Biology, 42, 231-233

31. Kostecka J., Pączka G. 2011. Kitchen wastes as a source of nitrogen and other macroelements according to technology of vermiculture. Ecological Chemistry and Engineering, A.18(12), 1683-1689.

32. Kostecka J., Pączka G., Garczyńska M., Podolak-Machowska A., Dunin-Mugler C, Szura R. 2014. Wykorzystanie wermikompostowania do zagospodarowania odpadów organicznych w gospodarstwach domowych. Inżynieria i Ochrona Środowiska, 17(1), 21-33. 
33. Krutwagen B., Kortman J., Verbist K. 2008. Inventory of Existing Studies Applying Life Cycle Thinking to Biowaste Management. Office of Official Publications of the European Communities, Luxembourg. [Available at: http://eplca.ire. ec.europa.eu/nploads/Waste-InYentorv-of-existing-stiidies-applving- life-cycł e-thinking-to-biowaste-management.pdf (accessed 2 August 2018).

34. Loh T.C., Lee Y.C., Liang J.B., Tan D. 2005.Vermicomposting of cattle and goat manures by Eisenia foetida and their growth and reproduction performance. Bioresource Technology, 96(1), 111-114.

35. Monier V, Mudgal S, Escalon V. 2010. Final report - Preparatory study on food waste across EU 27; European Commission [DG ENV - Directorate C]. Paris: BIO Intelligence Service, 1-205.

36. Padmavathiamma P. K., Li L. Y., Kumari U. R. 2008. An experimental study of vermin-biovaste composting for agricultural soil improvement. Bioresource Technology, 99, 1672-1681.

37. Paradelo R., Moldes A. B., Barral M. T. 2009. Properties of slate mining wastes incubated with grape marc compost under laboratory conditions. Waste Management, 29, 579-584.

38. Parvaresh A., Movahedian H., Hamidian L. 2004. Vermistabilization of Multicipal Wastewater Sludge with Eisenia fetida. Iranian Journal of Environmental Health, Science and Engineering, 1, 43-50.

39. Pączka G., Kostecka J. 2012. Trends in organic waste vermicomposting. In: Kostecka J., Kaniuczak J. (Eds.) Internetowa Promocja Nauki. Nauka dla gospodarki 3/2012. Practical Applications of Environmental Research, 22, 267-281. http:// www2.ur.edu.pl/wbr_monografie/Practical_Applications.pdf

40. Pączka G., Kostecka J. 2013. The influence of vermicompost from kitchen waste on the yieldenhancing characteristic of peas Pisum sativum L. Var. Saccharatum Ser. Bajka variety. Journal of Ecological Engineering, 14, 49-53.

41. Sangwan P., Kaushik C. P., Garg V. K. 2008. Feasibility of utylization of horse dung spiked filter cake in vermicomposters using exotic earthworm Eisenia foetida. Bioresource Technology, 99, 2442-2448.

42. Sapek A. 2013. Dissipation of fertiliser compo- nents from food treated as waste. Water-Environment-Rural Areas, 1(41), 129-142.

43. Sherman R. 2003. Raising earthworms successfully. North Carolina Cooperative Extension Service. North Carolina State University, Raleigh, NC, 1-26.

44. SinghR., Sharma R.R., Kumar S., Gupta R.K., Patil R.T. 2008. Vermicompost substitution influences growth, physiological disorders, fruit yield and quality of strawberry (Fragaria x ananassa Duch.). Bioresource Technology, 99, 8507-8511.

45. Song X., Liu M., Wu D., Griffiths B.S., Jiao J., Li H., Hu F. 2015. Interaction matters: Synergy between vermicompost and PGPR agents improves soil quality, crop quality and crop yield in the field. Applied Soil Ecology, 89, 25-34.

46. The Fertilisers and Fertilisation Act (Journal of Laws of the Republic of Poland, 28 June 2018, item 1259) [Avaiable at https://www.infor.pl/aktprawny/DZU.2018.124.0001259, ustawa-o-nawozach-i-nawozeniu.html, accessed 2 October 2018]

47. The National Waste Management Plan [KPGO 2022]. [Avaiable at https://www.mos.gov.pl/komunikaty/szczegoly/news/krajowy-plan-gospodarkiodpadami-2022/, accessed 2 October 2018].

48. The Regulation of the Minister of Economy of 16 July 2015 on landfill waste disposal (Journal of Laws of the Republic of Poland [Dz. U. RP], item 1277). [Avaiable at http://prawo.sejm.gov.pl/isap. nsf/DocDetails.xsp?id=WDU20150001277, accessed 2 October 2018]

49. The Regulation of the Minister of the Environment of 20 January 2015 on the process of R10 recovery (Journal of Laws of the Republic of Poland [Dz. U. $\mathrm{RP}]$, item 132).

50. Thematic Strategy on Soil Protection [COM (2002) 179], [COM (2006) 231], [COM (2006) 232]. [Available at: https://www.eea.europa.eu/policydocuments/soil-thematic-strategy-com-2006-231, accessed 2 October 2018]

51. Tripathi G., Bhardwaj P. 2004. Decomposition of kitchen waste amended with cow manure using an epigeic species (Eisenia fetida) and an anecic species (Lampito mauritii). Bioresource Technology, 92(2), 215-218. 